\title{
Survival of Tort Actions A Proposal for California Legislation
}

\section{Lawrence Livingston*}

For a sUBJEct which is neither esoteric enough to provoke academic discussion nor significant enough in the social sense to justify continual debate, few legal problems have been considered as frequently as the abatement and survival of tort actions. Since survival of such actions involving property has long been established, the phrase "survival of tort actions" customarily has been used to refer to actions for torts involving the person. It will be so used in this discussion.

Text writers have reviewed the case of abatement versus survival at length. ${ }^{1}$ Authors of law review articles have explored every phase of the question. ${ }^{2}$ Judges have handed down countless opinions wherem

*Member of the California Bar.

1Batdwin, The Law of Personal Injuries in Michigan 512-514, 638 (2d ed. 1909); 2 Beale, Conflict of Laws 1304-1305 (1935); 9 Blashfield, Cyctopedia of Automiobie Law and Practice 123-141 (1941); Burdick, Torts 288-289 (4th ed. 1926); CHapIN, Torts 117-131 (1917); CIERK \& LINDSEIr, ToRTs 88 (10th ed. 1947); 2 Cooley, Torts 149 (4th ed. 1932); Fiero, LAw and Practice in Action for Torts iN THE State of New York 143 (1903); HaIe, Damages 310 (2d ed. 1912); Harper, Torts 673-675 (1933); 2 Hopkns, Personal INJURIES 907 (1912); 2 KinkEAD, COMaIENTARIES ON TORTS 895 (1903); 4 Shearatan \& Redfield, Negligence 1868-1883 (Rev. ed. 1941); 6 Thontason, CoMaMentaries on tHe LAW of Negligence 149-151 (1905); TLFfany, Death BY Wrongeul ACT 32, 255-256 (2d ed. 1913); UNderemir, A Sudmatay of the Law of Torts 47-50 (15th ed. 1946). See also, 4 Restatement, TORTS $\$ \$ 900,925,926$ (1939).

2 Bogle, Construction of "Survival Act" and "Death Act" in Michigan (1911) 9 MrcH. L. Rev. 205; Corliss, Survival and Abatement of Action (1886) 33 ALBANY L. J. 184, 204; Estrich, Survival of Causes of Action for Libel and Slander, Malicious Prosecution and Nuisances under the Ohio Law (1932) 6 U. of CIN. L. REv. 404; Evans, Survival of the Action for Death by Wrongful Act (1933) 1 U. OF C표. L. REv. 102; Evans, Death by Wrongful Act-Survivorship of Tort Claims in Kentucky (1933) 21 KY. L. J. 369; Evans, Survival of Claims for and against Executors and Administrators (1931) 19 KY. L. J. 195; Evans, A Comparative Study of the Statutory Survival of Tort Clains for and against Executors and Administrators (1931) 29 MICH. L. REv. 969; Jones, Civil Liability for Wrongful Death in Iowa (1925) 10 Iowa L. BULL. 169; Killion, Wrongful Death Actions in California, Some Needed Amendments (1937) 25 CAIIF. L. REv. 170; Oppenheim, The Survival of Tort Actions and the Action for Wrongful Death -A Survey and a Proposal (1942) 16 Tulave L. Rev. 386; Schumacher, Rights of Action under Death and Survival Statutes (1924) 23 Mrcr. L. REv. 114; Winfield, Death as Affecting Liability in Tort (1929) 29 Cor. L. Rev. 239; Note, Survival of Personal Injury Actions: A Legislative Proposal (1936) 24 CaLIF. L. REv. 716; Comment, Abatement and Revival: Survival of Causes of Action: Suggested Legislation (1931) 
they have repeated in learned fashion what other judges had said about death and the tortfeasor. ${ }^{3}$ Over the last one hundred years, very little has been added to the sum of knowledge on the subject. From the adoption of Lord Campbell's Act ${ }^{4}$ in 1846 to the present time, there has been substantial agreement that there is no logic in permitting actions for injuries to property to survive while actions for injuries to persons must abate. All writers have favored the proposition that at least some tort actions involving persons should survive both the death of the tortfeasor and the death of the party injured. All have agreed that survival should be provided for by legislation.

As early as 1918, Dean Orrin K. McMurray concluded a brief dis-

19 CacIF. L. Rev. 289; Comment, Abatement and Revival: Survival of Actions: Public Liability Insurance (1929) 18 CALTr. L. REv. 44; Note, Review of Reccnt Cases (1918) 6 CALIF. L. Rev. 455, 466; Note, Survival of Right of Action of Person Injutred-Whether Administrator Can Recover for Wrongful Death and Also for Damage to the Estate before Death (1940) 19 CHI-Kent Rev. 110; Note, Torts-Right of Privacy-Survival of Action (1946) 46 Cor. L. Rev. 315; Note, Abatement and Survival of Actions: Actio Personalis Moritur Cum Persona (1928) 13 CoRN. L. Q. 596; Note, Inadequacies of English and State Stcrvival Legislation (1935) 48 Harv. L. Rev. 1008; Note, The Inadequacies of Existing "Wrongful Death" and "Survival" Legislation (1931) 44 Harv. L. REv. 980; Note, Effect of Statutes for Survival of Actions on Liability for Death by Wrongful Act (1902) 15 Harv. L. Rev. 854; Note, Strvival of Right of Privacy Action (1946) 41 III. L. REv. 114; Note, Wrongful Death Action as Exclusive of Survival Action in Illitrois (1940) 35 ILL. L. REv. 479; Note, Death by Wrongful Act-Sttrvival of Liability upon the Tortfeasor's Death (1910) 4 Ir工. L. Rev. 425 ; Comment, Survivorship and Wrongful Death Actions as Affected by Louisiana Act 239 of 1946 (1947) 4 Loyora L. REv. 75; Comment, Wrongful Death and Strvival of Tort Actions in Louisiana (1941) 1 Loyora L. Rev. 84; Note, Death by Wrongful Act-Effect of Double Death on Recovery under Minn. "Death" and "Survival" Statutes (1946) 44 Mich. L. Rev. 1146; Note, Actions-Survival-Lord Campbell's Act (1929) 27 MicH. L. Rev. 942 ; Note, Wrongful Death-Survival of Cause of Action on Death of Wrongdoer (1945) 30 MnNN. L. REv. 127; Note, Wrongful Death and Survival Acts-Two Catuses of Action or One (1918) 2 MINN. L. REv. 292; Note, Abatement and Revival-Survival of the Cause of Action for Loss of Services at Common Law and Under Modern Statutes (1932) 9 N. Y. U. I. Q. Rev. 344; Note, Survival of Personal Injury Actions in North Carolina (1946) 25 N. C. L. REv. 84 ; Comment, Danages for Wrongful Death (1948) 9 U. of PiTT. L. REv. 266; Note, The Wrongful Death Act as Afjected by the Survival Statute (1940) 15 ST. Joun's L. Rev. 58; Note, Survival of Causes for Personal Injuries and Related Wrongs in Missouri (1929) 14 ST. LouIs L. REv. 184; Note, Abatement and Revival-Death of the Wrongdoer (1940) 47 W. VA. L. Q. 58.

3 See cases collected in the following notes: (1941) 134 A. L.R. 717; (1938) 117 A.L.R. 574 ; (1938) 112 A.L. R. 343 ; (1934) 93 A. L. R. 1133; (1934) 92 A. L. R. 956; (1932) 78 A.I.R. 593, 600; (1932) 76 A. L. R. 403; (1931) 70 A. L. R. 1319; (1930) 67 A. L. R. 1159 ; (1929) 62 A. L. R. 1048; (1929) 61 A. L. R. 830 ; (1928) 57 A. L. R. 351 ; (1923) 24 A. I. R. 488 ; (1921) 14 A. L. R. 693 ; L. R. A. (1916 A) 1143; L. R. A. (1915 E) 1104 ; (1914) 52 L.R.A. (N.s.) 1215 ; (1909) 17 L.R.A. (N.s.) 570 ; (1908) 11 L.R.A. (N.S.) 1157; (1907) 5 L. R.A. (N.s.) 756.

4 Fatal Accidents Act, 1846, 9 \& 10 Vicr., c. 93. 
cussion of Hesler v. California Hospital Company $y^{5}$ with this question:

Is it not surprising that with all the progressive legislation on our statute books, the legislature has not yet seen fit to place California in the same position with regard to survival of actions as many of our sister states who do not boast of their progressiveness? ${ }^{6}$

Dean McMurray's views have been restated in many forms and in many publications. There has been no dissent from the proposition that tort actions should survive. However, there has been some disagreement on details. Survival statutes reflect this disagreement. For example, there are the questions of what types of tort actions should survive; what damages should be recoverable in the surviving action; whether one or more than one cause of action should flow from the same tort. These and cognate inquiries frequently accompany statements advocating survival legislation.

Interest in the subject was revived by the decision of the Supreme Court of California in Hunt v. Authier, decided in 1946. There the court expressed the unanimous opinion that there should be some form of survival in this state. Encouraged by this decision, protagonists of the survivorship principle have drafted legislation which they expect to present to the 1949 legislature for enactment. The purpose of this article is to submit to the bar for consideration and discussion proposed changes in the law of torts which are intended to provide for the survival of tort actions in what is believed to be the most satisfactory form.

\section{SURVTVAL LEGISLATION}

Both in England and in this country, the courts adhered to the proposition that tort actions involving persons did not survive either in favor of the successors to the injured party or against the successors of the tortfeasor in the absence of legislation. Apparently the first law providing for survival was an Ohio statute passed in $1831 .^{9}$ This statute permitted survival of pending actions for personal injuries. Since then, Great Britain ${ }^{10}$ and forty-two states ${ }^{11}$ have adopted

E (1918) 178 Cal. 764, 174 Pac. 654.

6 Note, Review of Recent Cases (1918) 6 CALIF. L. REv. 455, 466.

7 (1946) $28 \mathrm{Cal}$. (2d) 288, 196 P. (2d) 913.

8 Evans, A Comparative Study of the Statutory Survival of Tort Claims for and Against Executors and Admintistrators (1931) 29 MICH. L. REV. 969.

0 Crv. Proc. ACT (1831) \$\$62, 64.

10 Law Reform Act, 1934, $24 \& 25$ Geo. V, c. 4.

11 Ata. Code tit. 7, \$150 (1940); ARIz. COde ANN. \$21-534 (1939); Ark. Stats. Ann. § 27-901 (1947); ConN. GeN. Stats. ch. 321, §6030 (1939 Supp. to 1930 Rev.); 
survival legislation. The principle of survival became part of the Federal Employers Liability Act in $1908,{ }^{12}$ and in 1948 Congress provided for survival in the District of Columbia. ${ }^{13}$

As was suggested earlier in this article, there are substantial differences in the survivorship laws of various jurisdictions. In a few states only pending actions survive. ${ }^{14}$ In at least one state a statute which apparently provides generally for the survival of tort claims has been so limited in its scope by judicial legislation that it now applies only to pending actions. ${ }^{15}$ In Great Britain, ${ }^{16}$ the District of Columbia ${ }^{17}$ and seven states ${ }^{18}$ all torts involving persons survive. In these jurisdictions a right of action for personal injuries passes to the personal representative of a deceased injured party. Both this action and

DEL. REv. Code $§ 4638$ (1935) ; Fla. Stats. $\$ 45.11$ (1941); GA. LAws p. 94 (1935); IrL. ANn. Stats. (Smith-Hurd) ch. 3, \$ 494 (1943) ; Ind. Stats. ANN. \$§ 2-403, 2-405 (Burns 1946 Replacement 1933 ed.) ; IowA CODE $\$ 611.20$ (1946) ; KAN. GEN. STATS. § 60-3201 (1935, 1947 Supp.); Ky. Rev. Stats. \$ 411.140 (1948); La. Code of Practice Art. 25 (1942 2d ed.) ; LA. Civ. Code Art. 2315 (1945 2d ed.); Me. Rev. Stats. ch. 152, \$ 8 (1944); MD. ANn. Code Art. 93, § 109 (1939); Mass. Ann. Laws ch. 228, § 1 (1933); Mich. Stats. ANn. \$27.684 (1938); MInN. Stats. AnN. $\$ 573.01$ (1947); Miss. Code $\S 1453$ (1942) ; Mo. Rev. Stats. Anv. § 3670 (1942); Mont. Rev. Code ANn. § 9086 (1935) ; Neb. Rev. Stats. § 25-1401 (1943); Nev. Comp. Laws § 240.01 (1929, Supp. 1931-1941) ; N. H. Rev. Laws ch. 355, § 9 (1942) ; N. J. Stats. ANN. § 2.26-10 (1939); New Mex. Stats. ANN. \$ 19-701 (1941); N. Y. Dec. Estate Law \$§ 118, 119 (McKinney's Cons. Laws, Book 13, 1939) ; N. C. Gen. Stats. \$§ 28-172, 28-175 (1943) ; N. D. Rev. Code \$\$ 28-0218, 32-2105 (1943); OHIO GEN. CODE ANN. § 11235 (Page 1940); OkIA. Stats. AnN., tit. 12, § 1051 (1941); Ore. ConfP. Laws ANN. § 1-312 (1940); PA. Stats. ANN., tit. 20, $\$ 772$ (Purdon 1936); R. I. Gen. Laws ch. 512, §§ 1-2 (1938); S. C. Code of Laws $\$ 419$ (1942) ; S. D. CoDE $\$ 37.2201$ (1939 amended Session Laws 1947, ch. 172, 173); TENN. Code ANN. \$ 8243.1 (Williams 1934); Texas Crv. STats. $\S 5525$ (Vernon 1936); VT. STATS $\$ \$ 2921,2922$ (1947 Rev.); VA. COdE ANN. \$5790 (1947); Wis. Stats. § 331.01 (1947); Wyo. ContP. Stats. ANn. \& 3-402 (1945).

12 (1908) 35 STAT. $66 ; 45$ U.S. C. $\$ 53$ (1946 ed.).

13 PUB. L. No. 677, 80th Cong., 2d sess. (June 19, 1948).

${ }^{14}$ AIA. Code tit. 7, § 150 (1940); ArIz, Code ANN. \$ 21-534 (1939); Det. Rev. CODE $\$ 4638$ (1935) (pending action for personal injuries survives death of plaintiff); GA. LAws 94 (1935) (only pending action survives death of person injured, though cause of action survives death of wrongdoer); see also Peebles v. Charlestown \& W. C. Ry. Co. (1910) 7 Ga. App. 279, 66 S. E. 953; NEw MEx. STAT. ANN. \$§ 19-701, 19-704 (1941) (only pending action survives death of person injured, though causes of action for wrongful death and personal injuries survive death of party responsible); N. D. REv. Cone \$ 32-2105 (1943) (pending action for wrongful death survives death of defendant).

15 Webb v. French (1934) 228 Ala. 43, 152 So. 215; ArA. Code tit. 7, § 150 (1940).

10 See note 10 supra.

17 See note 13 supra.

18 Conn., Iowa, La., Miss, Mont., N.H., N. Y. In Nevada, all causes of action for personal mjuries survive, whether to the health, reputation, or person of the injured party, but a cause of action for wrongful death does not survive the death of the tortfeasor. See NEv. Coגr. Laws §§ 240.01, 9194, 9195 (1929) (Supp. 1931-1941). 
an action for wrongful death survive against the personal representative of a deceased tortfeasor.

In many jurisdictions actions which do not involve physical injury, such as defamation, false imprisonment, malicious prosecution and the like, survive. ${ }^{19}$ In other jurisdictions only actions involving physical injury or death survive. ${ }^{20}$

In some states the damages recoverable for the benefit of the estate of the injured party are exactly the same as the damages which he would have recovered had he lived. ${ }^{21}$ Thus, the personal representative of a deceased who had been injured in his lifetime may recover not only for the actual pecuniary loss of the deceased but also for the pain and suffering which he experienced. Other states limit the damages recoverable to actual pecuniary loss on the theory that the estate should only be enriched to the extent of the money loss of the deceased. ${ }^{22}$ Under certain statutes an action for wrongful death does not survive the death of the tortfeasor, ${ }^{23}$ but most survival statutes provide for survival of wrongful death claims. ${ }^{24}$

There is still another question which has troubled the courts considerably. Assume a case of personal injury followed by death result-

10 Ibid,; Mich. STats. ANN. \$ 27.684 (1938); Wis. Stats. § 331.01 (1947); Prosser, TORTs 953 (1941). See also, the classification of statutes in (1946) 46 CoL. L. REv. 315 at $316 ; 48$ HARv. L. REv. 1008 at $1009 ; 29$ MICH. L. REv. 969 at $975 ; 9$ N. Y. U. L. Q. REv. 344 at 348 .

20 Ark, Fla., Ill., Kan., Ky., Md., N. J., N. Mex., Ohio, Okla., Pa., R.I., Va. See (1935) 48 HARv. L. REv. 1008 at 1009 and (1931) 29 MICH L. REv. 969 at 976.

21 Ark., Conn., Fla., Ml., Kan., Ky., Mich., Mo., Mont., Neb., Nev., N.H., N. J., N. C., Ohio, Okla., R. I., S. C., S. D., Texas, Va., W. Va., Wyo.

22 Ga. Laws p. 95 (1935) ("... in event of the death of the wrongdoer before suit ... there shall be no punitive damages.") ; Iowa CODE $\$ 5611.20$ (1946) (In action commenced after death of party injured only damages to estate may be recovered, without regard to pain and suffering; Boyle v. Bornholtz (1937) 224 Iowa 90, 275 N. W. 479); ME. Rev. Stats. ch. 152, \& 8 (1944) (only loss sustained may be recovered in action against executor or administrator); N. Y. Dec. Estate LAw $\$ \S 118,119$ (1939) (". . . punitive damages shall not be awarded nor penalties adjudged.") ; WIs. STats. $\$ 331.01$ (1947) (no exemplary damages or for injuries to feelings). See D. C. CoDe of LAws $\S \S 235,237$ amended 1948 (PUB. L. No. 677, soth Cong., 2d sess. June 19, 1948): “ . . in tort actions the right of action shall be limited to damages for physical injury except pain and suffering resulting therefrom."

23 ARK. STAT. ANN. \$§ 27-901, 27-903 (1947); Nev. Comp. Laws \$240.01 (1929) (Supp. 1931-1941) ; S. C. CoDE § 419 (1942) (see Claussen v. Brothers (1928) 148 S. C. 1, 145 S. E. 539).

24 Ore., La., Kan., Minn., New Mex. and Tex. Crv. Stats. \$ 4676 (Vernon 1936). See Killion, Wrongful Death Actions in California, Some Needed Amendments (1937) 25 CaLIF. L. REv. 170 at 186; Oppenheim, The Survival of Tort Actions and the Action for Wrongful Death-A Survey and a Proposal (1942) 16 TOLANE L. Rev. 386 at 388; (1931) 44 HARv. L. REv. 980 at 981 ; (1929) 27 MICH. L. REv. 942. 
ing from the same tort. Should there be two causes of action, one in favor of the personal representative as successor of the deceased, and the other in favor of the heirs (or personal representative for the benefit of the heirs) for damages accruing as a result of the death? Should there be only one action upon the theory that there should not be two recoveries for the same tort? Should the nature of the action be dependent upon whether the injured party died instantaneously or lingered even momentarily? ${ }^{25}$ These questions have been answered by the legislators and by the courts in various ways. In some jurisdictions the statutes specifically provide for two actions ${ }^{26}$ in some, the courts have construed survival statutes to permit two actions. ${ }^{2 \pi}$ Others have held that there may be but one action; ${ }^{28}$ a few have held that the nature of the action depends upon whether the death was instantaneous or whether the deceased lingered. ${ }^{20}$

In preparing the legislation which is to be submitted to the 1949 Legislature, an effort has been made to give due consideration to all of these problems. In order to determine precisely what legislation is necessary to bring this state in line with the modern view of survivorship, we must first determine what the law in California is at present.

THE CAIIFORNIA LAW OF SURVTVAL

Until 1946 the law of California was the same as the law of England in 1846. Contract claims survived. ${ }^{30}$ Torts involving real and personal property survived. ${ }^{31}$ Lord Campbell's Act had been copied into California law..$^{32}$ Tort actions involving persons did not survive under any circumstances. ${ }^{33}$

254 Shearman aNd REDFIeId, NEGLIGENCE 1869 (1941).

20 Me. Rev. Stats. ch. 152 \& 8 (1944); N. Y. Dec. Estate Law $\$ 120$.

25 St. Louis, I.M. \& S. Ry. Co. v. Hesterly (1911) 98 Ark. 240, 135 S. W. 874; Stephens v. Columbus R. Co. (1910) 134 Ga. 818, 68 S. E. 551 ; Royal Indemnity Co. v. Pittsficld Elec. Co. (1935) 293 Mass. 4, 199 N. E. 69 ; Prudential Ins. Co. of America v. Laval (1942) 131 N. J. Eq. 23, 23 A. (2d) 908; St. Louis \& S. F. R. Co. v. Goode (1914) 42 Okla. 784, 142 Pac. 1185; Stegner v. Fenton (1945) 351 Pa. 292, 40 A. (2d) 473. See Oppenheim, sutpra note 24 at 389; Schumacher, Rights of Action Under Death and Survival Statutes (1924) 23 MICr. L. Rev. 114 at 124; (1940) 19 CHI-KENT Rev. 110; (1902) 15 HaRv. L. Rev. 854; (1946) 25 N. C. L. REv. 84 at 87.

$28 \mathrm{McWhorter}$ Transfer Co. v. Peck (1936) 232 Ala. 143, 167 So. 291; Chase v. Fitzgerald (1946) 132 Conn. 461, 45 A. (2d) 789; Chochran v. Laton (1918) 78 N.H. 562,103 Atl. 658.

294 Shearman and Redfietd, Negrigence 1869 (see cases cited 1948 Supp.); (1940) 19 Chi-Kent Rev. 110 at 111.

30 CaL. Prob. COdE $\$ 573$.

31 Id. $\$ 574$.

32 CAL. Code Civ. Proc. $\$$ 376, 377.

33 Sections 376 and 377 of the Code of Civil Procedure do not provide for survival. 
In 1946, Hunt v. Authier ${ }^{34}$ burst upon the unsuspecting bench and bar of California. This was an action against the personal representative of Ephrem Mounsey, who deliberately shot Dr. Verne C. Hunt, and then committed suicide. The widow and the children of Dr. Hunt filed a claim against Mounsey's estate for "waste and destruction of their property, property rights and estate." ${ }^{35}$ The ingenuity and courage of the lawyer who evolved this idea provokes both admiration and envy. However, the claim was rejected and an action was filed. The trial court sustained a demurrer to the complaint; the supreme court, by a four-to-three decision, reversed.

The court held that the action survived because of a slight difference between the phraseology of former section 1584 of the Code of Civil Procedure and that of section 574 of the Probate Code, enacted to replace section 1584 . Section 1584 provided for the survival of an action involving waste, destruction, taking, carrying away, or converting "goods or chattels"; 36 section 574 changed the phrase "goods and chattels" to "property." The court points out that the modern view of the law is that tort claims should survive, and concludes that the change from "goods and chattels" to "property" indicated an intent on the part of the Legislature to change the law. It reaches the following result:

Injuries suffered by the plaintiffs by the lessening of their estate and the invasion and deprivation of their pecuniary interests and right to future support from their decedent by the commission of the wrongful act is as much a destruction of or injury to property as was involved in the foregoing cases; and the tort likewise in this case should be deemed to be an invasion of their property rights within the meaning of the present statute. ${ }^{37}$

They provide an action for wrongful death, which arises upon death. Some of the cases denying survival are: Norton v. City of Pomona (1935) 5 Cal. (2d) 54, 53 P. (2d) 952; Munchiando v. Bach (1928) 203 Cal. 457, 264 Pac. 762; De La Torre v. Johnson (1927) 200 Cal. 754, 254 Pac. 1105; Clark v. Goodwin (1915) 170 Cal. 527, 150 Pac. 357 ; Harker v. Clark (1881) 57 Cal. 245; Gosling v. Nichols (1943) 59 Cal. App. (2d) 442, 139 P. (2d) 86; Phillips v. Gonzales (1941) 44 Cal. App. (2d) 267, 112 P. (2d) 272; Rideaux v. Torgrimson (1940) 39 Cal. App. (2d) 273, 102 Pac. (2d) 1104; Reider v. Aqueduct Construction Co. (1939) 32 Cal. App. (2d) 90, 102 P. (2d) 1104; Speer v. Brown (1938) 26 Cal. App. (2d) 283, 79 P. (2d) 179; Smith v. Bimini Income Properties, Inc. (1934) 138 Cal. App. 447, 32 P. (2d) 399; Singley v. Bigelow (1930) 108 Cal. App. 436, 291 Pac. 899; Severns v. Calif. Highway Indemnity Exchange (1929) 100 Cal. App. 384, 280 Pac. 213.

34 (1946) 28 Cal. (2d) 288, 169 P. (2d) 913.

35 Id. at $289,169 \mathrm{P}$. (2d) at 914.

36. This phrase was undoubtedly borrowed from 4 EDw. III, c. 7 (1330).

37 Supre note 34 at 296,169 P. (2d) at 918. 
A dissenting opinion recognizes that tort claims should survive, but expresses the view that the majority had invaded the legislative field. It argues that the single word "property" could not make section 574 a general survival statute which would accomplish the purposes sought for years by sponsors of survival legislation.

To these sponsors the majority opinion will come as a distinct surprise, for they will learn for the first time that their attempts to obtain general survival legislation in each session of the Legislature held since the adoption of the Probate Code in 1931, have been wholly unnecessary, as such general survival legislation had been enacted, without coming to their attention, as part of that code. Their surprise will no doubt be shared by the legislators who voted for the enactment of the Probate Code as well as by the members of the bench and bar. ${ }^{38}$

After reading both opinions it appears to the writer that the minority has the stronger argument. This is not important at this juncture; Hunt v. Authier is now the law of California. The most important thing to be derived from both opinions is that the seven justices have clearly and unmistakably expressed the view that the law ought to provide for survivorship of tort actions.

The commentators on Hunt v. Authier unanimously state, first, that tort actions should survive, and second, that the majority opinion is wrong. ${ }^{39}$ Lawyers throughout the state have engaged in lively discussion of the supreme court's revolutionary decision. As usual, points of view have been influenced by the respective interests of clients. However, is is fair to say that most members of the profession are of the opinion that the decision was wrong although the result was desirable.

For the present, at least, we may assume that Hunt v. Authier is the law of California, unless a change in supreme court personnel or a change in a judge's mind results in its repudiation. On the basis of the experience of the bar with United States Supreme Court decisions, it may fairly be said that uncertainty exists and will continue to exist until the law is crystallized by legislation. ${ }^{40}$ The present state of the

${ }^{38} \mathrm{Id}$. at $297,169 \mathrm{P}$. (2d) at 919.

39 (1946) 34 CALIF. L. REv. 613; (1946) 26 NEB. L. REv. 128, 129; (1946) 21 ST. JoHn's L. REv. 111, 112; (1947) 20 So. CALIF. L. REv. 239.

40 In the California Law Review, a note on the decision points out that innumerable difficulties will arise as the result of the Hunt decision unless there is supplemental legislation. The writer concludes: "It is submitted that although the Hunt case has brought about a desirable result in some situations, many gaps remain in the California survival statutes. These gaps should be filled by legislation plainly providing that all 
law poses a number of questions which only legislation can solve. It must be obvious that Hunt v. Authier compels a reinvestigation of Dean McMurray's rhetorical question concerming Califormia's failure to join other states in modernizing the law. ${ }^{41}$

\section{PROPOSED SURVIVAL LEGISLATION}

The writer now submits a series of proposed amendments to various codes, the purpose of which is to incorporate by legislation, rather than by judicial interpretation, a comprehensive scheme for the survival of tort actions. The ain of the draftsmen is to cover all of the possible differences of opimion which have plagued commentators, judges, and other draftsmen. Although it has been suggested on occasion that a uniform statute providing for survival should be prepared, ${ }^{42}$ it is the view of the writer that in California we should attempt to retain as much of the present law as circumstances will permit.

Almost a century of judicial decision has built up a respectable body of California common law. Indefinite statements such as "such damages may be given as under all the circumstances of the case may be just" 43 and "the measure of damages ... is the amount which will compensate for all the detriment proximately caused" 44 have now a definite meaning. ${ }^{45}$ The approach to law via a system of codes is

pecuniary losses suffered as a result of wrongful death or other injury should survive the death of the wrongdoer or of the victim." 34 CALIF. L. REv. 613, 617.

The Hunt case has now been cited as a precedent to uphold the survival of an action for slander of title (Smith v. Stuthinan (1947) 79 Cal. App. (2d) 708, 181 P. (2d) 123), an employer's action for personal injuries to his employee under Section 3852 of the Labor Code (City of Los Angeles v. Howard (1947) 80 Cal. App. (2d) 728, 182 P. (2d) 278), an action for wrongful death where the tortfeasor died (Nash v. Wright (1947) 82 Cal. App. (2d) 475, 186 P. (2d) 691), an action against a hife insurance company for negligent failure to act upon an application for insurance (Sinith v. Minnesota Mutual Life Insurance Co. (1948) 86 A. C. A. 615, 195 P. (2d) 451), and an action for personal injuries (Moffatt v. Smith (1948) 87 A. C. A. 877, 197 P. (2d) 798). In these cases the various district courts of appeal have carefully refrained from discussing the reasons supporting the $H$ unt rule, except in Moffat $v$. Snith, where a concurring opinion agreed with the minority of the supreme court but recognized the binding authority of the majority decision.

41 (1918) 6 CALIF. L. REv. 455, 466.

42 Oppenheim, The Survival of Tort Actions and the Action for Wrongful DeathA Survey and a Proposal (1942) 16 Tulane L. Rev. 386; Prosser, TorTs 971.

43 CAL. Code Civ. Proc. \$ 377.

44 Car. Civ. Code $\$ 3333$.

45 Roedder v. Lindsley (1946) 28 Cal. (2d) 820, 172 P. (2d) 353; Estate of Riccomi (1921) 185 Cal. 458, 197 Pac. 97; Storrs v. Los Angeles Traction Co. (1901) 134 Cal. 91, 66 Pac. 180; Duclos v. Tashjian (1939) 32 Cal. App. (2d) 444, 90 P. (2d) 140; In re Cahfornia Nav. \& Imp. Co. (N. D. Cal. 1901) 110 Fed. 670, 8 CAL. JUR. 808, 1002, 1003. 
customary with California lawyers. They are in the habit of cataloging their legal thinking in accordance with the appropriate codes. ${ }^{46}$ Therefore, instead of enacting a law which will cover all of the subjects incidental to survival, it would seem advisable to amend the pertinent sections of the various codes and to add new code sections where required. Consequently, there are proposed amendments to the Civil Code, the Code of Civil Procedure, the Probate Code, the Vehicle Code and the Insurance Code.

In preparing these amendments, due consideration has been given to all of the problems posed by existing legislation and judicial decisions. The conclusions reached will now be stated and, as briefly as possible, an attenipt will be made to justify these conclusions.

1. Should all torts involving the person survive or should survival be limited to torts which inflict physical injury? It is submitted that only actions involving physical injury and death should survive. Torts which survive in some jurisdictions but which would not survive under the proposed legislation are wrongful arrest, false imprisonment, malicious prosecution, invasion of the right of privacy and defamation in its various phases. It is believed that the reasons for this choice are sound.

There is no social justification for requiring such causes of action to survive. Persons injured by torts which do not cause physical injury are seldom, if ever, deprived of the ability to maintain themselves. Certainly there is no risk that such injured persons may become public charges. Those who are physically injured frequently have earning power permanently cut off, or at least seriously impaired.

Furthermore, a study of the judgments rendered in tort cases which do not involve physical injury leads inevitably to the conclusion that although the damages are denominated partially pecuniary and partially punitive, the pecuniary damages are minimal and these judgments are, in fact, largely punitive. Judgments for thousands of dollars have been awarded for a few days' imprisonment which has caused considerable discomfort but little or no money damage. ${ }^{47}$ The Supreme Court of California has upheld a judgment of $\$ 10,000$ for

46 With the numerous codes now existing it is doubtful whether there is still only "one code" in California.

47 Peckham v. Warner Bros. Pictures, Inc. (1940) 42 Cal. App. (2d) 187, 108 P. (2d) 699; Porter v. Gramich (1934) 136 Cal. App. 523, 29 P. (2d) 220; Collins v. Jones (1933) 131 Cal. App. 747, 22 P. (2d) 79. See Notes, (1926) 40 A. L. R. 297 (excessivoness or madequacy of judgment in action for false imprisonmeut or for malicious prosecution); (1927) 47 A.L.R. 312. 
seduction although there was actually no financial loss whatsoever. ${ }^{48}$ Enormous verdicts for libel have been upheld, but the out-of-pocket loss in such cases usually is negligible. ${ }^{49}$ It was recently reported in the public press that a woman in St. Louis was awarded $\$ 290,000$ because a motion picture invaded her right of privacy and cheapened her character!

There is no reason why the estate of a dead man should be enriched because of humiliation, embarrassment or even anguish suffered by the deceased in his lifetime. There is little reason why the estate of a dead man should be required to respond in damages because of humiliation, embarrassment, or anguish caused by the deceased in his lifetime.

Finally, and perhaps most important, a judgment flowing from a physical injury need not cause any loss to the estate of the deceased tortfeasor. Practically all torts involving physical injury, excepting deliberate injury or killing, can be covered by liability insurance, and the mythical "ordinary prudent man" carries such insurance. The Motor Vehicle Code practically requires such insurance, at least to a limited extent..$^{50}$ Automobile finance compamies frequently demand liability insurance. Such insurance on real property is generally recommended by banks and other lending agencies.

Thus, there is a real difference between torts causing physical injuries and other torts. This difference may properly be recognized in a survival statute. It is conceivable that the legislature will disagree with this view; if so, the proposed legislation will be amended accordingly.

2. Should the personal representative recover the same damages as would have been recovered by his decedent or should the damages be limited to pecuniary losses? ${ }^{51}$ It does not seem reasonable that an es-

48 Carter v. Murphy (1938) 10 Cal. (2d) 547, 75 P. (2d) 1072.

49 Earl v. Times Mirror Co. (1921) 185 Cal. 165, 196 Pac. 57; Behrendt v. Times Mirror Co. (1938) 30 Cal. App. (2d) 77, 85 P. (2d) 949; Ballard v. Krug (1931) 111 Cal. App. 555, 295 Pac. 871 ; Newby v. Times Mirror Co. (1920) 46 Cal. App. 110, 188 Pac. 1008.

50 California Vehicle Code sections 410,413 , and 420 provide for the suspension of the license of any operator of a motor vehicle who fails to pay any judgment for damage to property up to $\$ 1,000$, or for personal injury to or death of one person up to $\$ 5,000$, or up to $\$ 10,000$ if personal injury or death results to more than one person in any one accident. These amounts are minimums in liability imsurance policies. Evidence of financial responsibility is also required. Section 414 provides for insurance as such evidence.

51 In personal injury cases, such losses would include out-of-pocket expenses and loss of earnings; in death cases, loss of consortium and support money and the expense of the funeral. 
tate should be enhanced by the value placed by a jury upon the pain and suffering experienced by a dead man. The deceased bore the pain and suffering and he is the only one who should be compensated. $\mathrm{He}$ can't take it with him. Yet, in many jurisdictions the estate collects for the pain which had been suffered by one who is dead. This smacks of punishment and not reimbursement.

The proposed amendments limit recovery by the estate of the injured party to "actual pecuniary losses" and specifically exclude "damages ... for pain, suffering, or disfigurement." Of course, in the case of a deceased tortfeasor the measure of damages should not be changed since the injury to the plaintiff is not affected by the death of the wrongdoer.

3. Should wrongful death actions survive? There is no reason for treating such actions differently fron personal injury actions.

4. Where the injured party dies subsequent to the injury and as a result of the tort, should two actions be permitted-one wherein the rights of the injured party are taken over by his representative, and the other where the action is prosecuted for the benefit of his heirs? It is suggested that two actions should be permitted upon two conditions: (1) that the same daniages are not collected twice, and (2) that the damages are not allowed to exceed reasonable limits. These conditions are met by limiting damages for injuries to actual pecuniary losses and to daniages which accrue before the death and by excluding pain and suffering. The heirs will recover the same damages as they do under the present law. Since the heirs' claim is an entirely different cause of action, ${ }^{52}$ there is no logical reason for limiting recovery to one action. Certainly there is no excuse for making the remedy depend upon how long the deceased survived the injury..$^{63}$

The proposed amendments are now submitted. The first is the addition of a new article to Chapter I of Title II of Part III of Division Second of the Civil Code. In order that the chapter may read properly, it has been necessary to divide it into two articles. The title of the chapter is "Things in Action." Article I will be headed "Transfer of Things in Action." Then follows Section 953 which defines a thing in action. Section 954 provides for transfer and descent of a thing in action, and Section 955 provides for the transfer of a conditional sale contract.

52 PROSSER, TORTS 956, 965.

53 For a full discussion of these questions see 4 ShEARMan ano REDFIELD, NEGLiGENCE 1868-1883. 
The new article will read as follows:

\section{Article II}

\section{Survival of Tort Actions}

956. A thing in action arising out of a wrong which results in physical injury to the person or out of a statute imposing liability for such injury sliall not abate by reason of the death of the wrongdoer or any other person liable for damages for sucli injury, nor by reason of the death of the person injured or of any other person who owns any sucli thing in action. When the person entitled to maintain such an action dies before judgment, the damages recoverable for such injury shall be limited to loss of earnings and expenses sustained or incurred as a result of the injury by the deceased prior to his death, and sliall not include damages for pain, suffering or disfigurement, nor punitive or exemplary damages, nor prospective profits or earnings after the date of death. The damages recovered shall form part of the estate of the deceased. Nothing in this article shall be construed as nraking sucl a thing in action assignable.

The sections which now provide for wrongful death actions are Sections 376 and 377 of the Code of Civil Procedure. Section 376 gives a parent a right of action for injury to or death of an unmarried minor child. Section 377 provides for an action for the death of an adult or a married minor. There seems to be no logical reason for providing for some deaths in Section 376 and other deaths in Section 377. Therefore, it was decided to limit Section 376 to actions for injuries to minors and provide therem for the survival of such actions. Section 377 has been rewritten to provide an action for wrongful death in all cases, with provision for survival. In these sections and those which follow amendments are italicized. The redrafted sections follow:

376. The parents of a legitimate unmarried minor child, acting jointly, may maintain an action for injury to such child caused by the verongful act or neglect of another. If either parent shall fail on demand to join as plaintiff in such action or is dead or cannot be found, then the other parent may maintain such action and the parent, if living, who does not join as plaintiff must be joined as a defendant, and before trial or hearing of any question of fact, must be served with summons either personally or by sending a copy of the summons and complaint by registered mail with proper postage prepaid addressed to such parent's last known address with request for a return receipt. If service is made by registered mail the production of a return receipt purporting to be signed by the addressee shall create a disputable presumption that such summons and complaint 
have been duly served. In the absence of personal service or service by registered mail, as above provided, service may be made as provided in Sections 412 and 413 of this code. The respective rights of the parents to any award shall be determined as an issue in the case and shall be declared in the judgment.

A mother may maintain an action for such an injury to her illegitimate unmarried minor child. A guardian may maintain an action for such an injury to. his ward.

Any such action may be maintained against the person causing the injury, or if such person be dead, then against his personal representative. If any other person is responsible for any such wrongful act or neglect the action may also be maintained against such other person, or his personal representative in case of his death. The death of the child or ward shall not abate the parents or guardian's cause of action for his injury as to damages accruing before his death.

If an action arising out of the same wrongful act or neglect may be maintained pursuant to Section 377 of this code for wrongful death of any such child the action authorized by this section shall be consolidated therewith for trial on motion of any interested party.

377. When the death of a person not being a minor, or when the death of a minor person who leaves surviving him either a husband or wife or child or children or father or mother, is caused by the wrongful act or neglect of another, his heirs or personal representatives may maintain an action for damages against the person causing the death, or in case of the death of such wrongdoer, against his personal representatives, whether the wrongdoer dies before or after the death of the person injured. If any other person is responsible for any such wrongful act or neglect, the action also may be maintained against such other person, or in case of his death, his personal representatives. In every action under this section, such damages may be given as under all the circumstances of the case may be just, but shall not inchide damages recoverable under Section 956 of the Civil Code. The respective rights of the heirs in any judgment shall be determined as an issue in the case and shall be declared in the judgment. Any action brought by the personal representatives of the decedent pursuant to the provisions of Section 956 of the Civil Code may be joined with an action brought pursuant to the provisions of this section. If an action be brought pursuant to the provisions of this section and a separate action be brought pursuant to the provisions of Section 956 of the Civil Code, such actions shall be consolidated for trial on the motion of any interested party. ${ }^{54}$

54 The changes proposed in sections 376 and 377 differ from those recommended by the Committee on Administration of Justice of the State Bar of Californin with respect to the determination of the respective rights in the judgment. See note 56, infra. 
It will be noted that Section 376, as redrafted, permits both parents to bring the suit for injury to the minor, or if one shall refuse to join, then such parent may be made a defendant. The purpose of this provision is to give the two parents an equal right so that the section may be consistent with Section 197 of the Civil Code, which gives both parents an equal right to the custody, service and earnings of the child.

The next section which requires amendment is Section 573 of the Probate Code. In its present form this section provides for actions for the recovery of property and actions on contract by and against executors and administrators. The amended section will include "wrongs resulting in physical injury or death." This is a simple survival statute. Ex industria the draftsmen have included the words, "or injury to property" not because the present state of the law re-" quires such addition, but because neither Section 573 nor Section 574 refers to injury to property.

The proposed amended section reads as follows:

573. Actions for the recovery of any property, real or personal, or for the possession thereof, or to quiet title thereto, or to enforce a lien thereon, or to determine any adverse claim thereon, and all actions founded upon contracts, or upon any liability for physical injury, death or injury to property, may be maintained by and against executors and administrators in all cases in which the cause of action whether arising before or after death is one which would not abate upon the death of their respective testators or intestates, and all actions by the State of Califorma or any political subdivision thereof founded upon any statutory liability of any person for support, maintenance, aid, care or necessaries furnished to him or to his spouse, relatives or kindred, may be maintained against executors and administrators in all cases in which the same might have been maintained against their respective testators or intestates.

It will be remembered that in the Hunt case a claim in probate was filed pursuant to Section 707 of the Probate Code. The present section, for obvious reasons, does not refer to claims for personal injuries or death. It also does not refer to injury to property, waste, destruction or the like. Although the task of the draftsmen of survival statutes does not include revision of probate law, it seemed logical and reasonable to provide for the filing of claims in tort cases as well as in contract cases. Therefore, Section 707 has been revised to read as follows:

707. All claims arising upon contract, whether they are due, not due, or contingent, and all claims for funeral expenses and all claims for 
damages for physical injuries or death or injury to property or actions provided for in Section 574 of this code, must be filed or presented within the time limited in the notice or as extended by the provisions of Section 702 of this code; and any claim not so filed or presented is barred forever, unless it is made to appear by the affidavit of the claimant to the satisfaction of the court or a judge thereof that the claimant had not received notice, by reason of being out of the state, in which event it may be filed or presented at any time before a decree of distribution is rendered. The clerk must enter in the register every claim filed, giving the name of the claimant, the amount and character of the claim, the rate of interest, if any, and the date of filing.

The Vehicle Code also requires revision. Section 402 of this code creates vicarious liability through imputed negligence to the owner of - the motor vehicle. Since this is a cause of action which is purely statutory, it was deemed advisable to add a subsection reading as follows:

(g) No action provided for in this section shall abate by reason of the death of any injured person or of any person liable or responsible under the provisions of this section.

The provisions for insurance in the Vehicle Code will also require amendment. Therefore, Section 415 (a) will require a new subparagraph, to read as follows:

415(a) (4) Such policy shall contain a provision that whenever judgment is secured against the insured or the executor or administrator of a deceased insured, in an action brought by the injured person or by his personal representatives, in the case of an action for personal injuries, or in an action brought by the heirs or personal representatives of the deceased, in the case of an action for wrongful death, then an action may be brought against the insurer on the policy and sub. ject to its terms and limitations, by such judgment creditor to recover on the judgment. 55

Finally, it was found necessary to amend the Insurance Code. Section 11580 provides for the form of policies of liability insurance. One of the provisions required by the statute is that an injured person or his heirs, or personal representatives in case of wrongful death, may brimg an action against the insurer on the policy after judgment against the tortfeasor. In order to make certain that this action will survive, the last paragraph (b) (2), of the section has been redrafted to read as follows:

55 The proposed amendment to section 415 (a) of the Vehicle Code is not recommended by the Committee on Administration of Justice. The original draft of the legislation was prepared by a subcommittee of the Committee on Administration of Justice of which subcommittee the writer is a member. 
(2) A provision that whenever judgment is secured against the insured or the executor or administrator of a deceased insured, in an action brought by the injured person or by his personal representatives, in the case of an action for personal injuries, or in an action brought by the heirs or personal representatives of the deceased, in the case of an action for wrongful death, then an action may be brought against the insurer on the policy and subject to its terms and limitations, by such judgment creditor to recover on the judgment.

These are the only changes which are considered necessary. It is submitted that this legislation makes appropriate and logical provision for the survival of tort actions without completely rewriting the California statutes and without losing the benefit of existing precedents. However, it is entirely possible that members of the bar and students of the law may be able to offer valuable suggestions not only with reference to the proposals stated above, but also with reference to other statutory law. Since the subject of survival is one of general interest and within the experience of most practitioners, it is hoped that this article will provoke extensive discussion and consideration of the problem. ${ }^{56}$

Communications addressed to the School of Jurisprudence will be gratefully received and will be given serious consideration. It is suggested, however, that all such communications be sent as promptly as possible so that they may be considered in connection with the presentation of survival legislation to the current session of the legislature. With the cooperation of the entire bar, California may indeed take its place with her sister states which have already placed "progressive legislation" upon their statute books.

${ }^{56}$ After completing the first draft of this article, the writer conferred with Professor Stanley Surrey's class in Legislation at the School of Jurisprudence of the University of California and with the Committee on Administration of Justice. Many of the suggestions of the students have been incorporated into the proposed statutes and amendments. Except as noted, the proposals have been approved by the Committee. 